\title{
The Robust Relationship between Taxes and U.S. State Income Growth
}

\begin{abstract}
I estimate the relationship between taxes and income growth using data from 1970-1999 and the forty-eight continental U.S. states. I find that taxes used to fund general expenditures are associated with significant, negative effects on income growth. This finding is generally robust across alternative variable specifications, alternative estimation procedures, alternative ways of dividing the data into "five-year" periods, and across different time periods and Bureau of Economic Analysis (BEA) regions, though state-specific estimates vary widely. I also provide an explanation for why previous research has had difficulty identifying this "robust" relationship.
\end{abstract}

\section{INTRODUCTION}

long-standing research enterprise has been devoted to Alestimating the effect of taxes on economic growth in U.S. states. To the extent a consensus exists, it is that taxes used to fund transfer payments have small, negative effects on economic activity. When used to fund productive expenditures, the associated tax effects are often estimated to vanish, or even become positive (Helms, 1985; Bartik, 1991; Phillips and Goss, 1995; Wasylenko, 1997). However, even this modest conclusion is disputed, since estimated effects vary widely across studies (Bartik, 1991; McGuire, 1992; Wasylenko, 1997).

Given the scores of studies that have investigated this issue, it is surprising that many important estimation issues are often not addressed. My study takes up several of these, and re-estimates the relationship between taxes and income growth. I find that taxes used to fund general expenditures are associated with significant, negative effects on income growth. Further, I show that these effects are generally robust across estimation procedures, alternative specifications of the regression equation, different time divisions of the data, and across time periods and Bureau of Economic Analysis (BEA) regions. I also provide a possible explanation for why previous research has had difficulty identifying these effects.

My analysis addresses the following estimation issues. First, it uses economic theory to derive an estimable equation. With respect to specification of the regression equation, theory has consequences for the following: (1) the inclusion/exclusion of labor, capital, and population variables along with,
National Tax Journal

Vol. LXI, No. 1

March 2008 
or instead of, underlying parameters such as saving, depreciation, and population growth rates; (2) the inclusion/exclusion of a lagged dependent variable; and (3) whether to include other explanatory variables in level or differenced forms.

The Cobb-Douglas production function has now become a standard point of departure for models of economic growth. Studies that have analyzed U.S. state fiscal policy ${ }^{1}$ within this framework include Merriman (1990), Garcia-Milá and McGuire (1992), Evans and Karras (1994), Holtz-Eakin (1994), Garcia-Milá, McGuire, and Porter (1996), Aschauer (2000), Yamarik (2000), and Shioji (2001). My study follows suit by employing a general version of the Cobb-Douglas production function that includes the textbook Solow model and the augmented, human capital model of Mankiw, Romer, and Weil (1992) as special cases.

A second specification issue concerns the role of time. Much of the previous literature has restricted taxes to have only contemporaneous effects on economic activity. When dynamic effects are incorporated, it is usually done indirectly, through the inclusion of a lagged income variable (e.g., Helms, 1985). My regression specifications allow taxes to have both contemporaneous and lagged effects. ${ }^{2}$

A related issue concerns how to define the length of a time period for time series observations of states. Previous research on state-level taxes and growth has relied almost exclusively on either cross-sectional (e.g., Romans and Subrahmanyam, 1979; Mullen and Williams, 1994; Yamarik, 2000) or annual panel data (e.g., Helms, 1985; Crain and Lee, 1999).
Cross-sectional data is undesirable because it ignores time-varying behavior in the explanatory variables. This is particularly a problem for taxes: The average state tax burden in 1999 was very close to its level in 1970 (cf. Reed, 2006, Figure $1)$, despite large variation over time. Cross-sectional analyses also suffer from omitted variable bias due to uncontrolled fixed effects-to the extent these are not picked up in initial income levels.

On the other hand, annual data is particularly vulnerable to measurement error bias. This is, again, of particular relevance for tax studies. Using two very different approaches, Reed and Rogers $(2006,2007)$ estimate that roughly one-half of the annual variation in tax burden is due to factors other than tax policy. This bias is exacerbated by the inclusion of state fixed effects. Further, annual state-level income data are characterized by substantial serial correlation (cf. Evans and Karras, 1994). The combination of serial correlation with a lagged dependent variable produces inconsistent estimates.

Multi-year interval data also suffer from these problems, but to a lesser degree: Measurement errors are more likely to cancel out over longer time periods. Serial correlation is less severe when observations are distanced further in time. A few studies have analyzed the effects of fiscal policy using multiple-year interval data. These include Garcia-Milá et al. (1996), Aschauer (2000), Shioji (2001), Chernick (1997), Tomljanovich (2004), and Bania, Gray, and Stone (2007), though only the latter three directly study taxes. My analysis estimates tax effects over 30 years using five-year interval data.

1 The subsequent discussion of previous research restricts itself to state-level analyses in which the dependent variable is income or income growth, where income is measured either by Personal Income or Gross State Product in either total or per capita terms.

2 Tomljanovich (2004) also allows for dynamic tax effects, but his study only includes state taxes, not state and local. The practical implication of this is that it ignores property taxes, among others, and locally financed public expenditures. The empirical importance of these is demonstrated by Helms (1985). 
A third issue is the selection of "control variables." Growth theory is sufficiently general that many variables are potential determinants of growth. Despite this, many studies of tax effects include no, or only a few, non-fiscal variables other than initial/lagged income, time, and/or state-fixed effects (cf. Becsi, 1996; Tomljanovich, 2004; Yamarik, 2000). Helms (1985) includes variables for state wages, percent unionization, and population density. Mullen and Williams (1994) include variables for growth of the civilian labor force, and the growth rates of private and public capital. Bania et al. (2007) employ the unemployment rate, percentage of the population that is working age, and union membership rates. Only Chernick (1997) and, notably, Crain and Lee (1999) have a broad set of control variables. My study includes an extensive set of control variables to avoid problems of bias associated with omitted variables.

That being said, it is well known that coefficient estimates are often highly dependent upon the particular set of variables included in the regression equation (Leamer, 1985; Levine and Renelt, 1992; Crain and Lee, 1999; Sala-i-Martin, 2004). To address this problem, I employ model selection criteria to determine variable selection. Further, I investigate the robustness of my results to alternative specifications.

A fourth issue concerns the choice of estimation procedure. Panel data are potentially characterized by complex error structures. Most previous research on fiscal policy uses Ordinary Least Squares (OLS) (e.g., Garcia-Milá and McGuire, 1992; Chernick, 1997; Crain and Lee, 1999), or OLS with standard errors corrected for general heteroscedasticity (e.g., Aschauer, 2000; Tomljanovich, 2004) or serial correlation (Evans and Karras, 1994). A few studies employ feasible Generalized Least Squares (FGLS) to address random effects (Garcia-Milá et al., 1996; Helms,
1985; Holtz-Eakin, 1994), though this procedure is usually rejected in favor of OLS with fixed effects. Dynamic panel data (DPD) estimators have occasionally been used to obtain consistent estimates when the regression specification includes both a lagged dependent variable and fixed effects (Holtz-Eakin, 1994; Shioji, 2001; and Bania et al., 2007). My analysis allows for a variety of serial correlation, heteroscedasticity, and cross-sectional correlation behaviors in the error term. It investigates the robustness of estimating tax effects using alternative OLS, FGLS, and DPD estimators.

A fifth issue addresses the role of influential observations. Point estimates may mask the fact that results can be driven by just a few time periods, or just a few states. This is of particular importance to policymakers who are interested in extrapolating the results of empirical studies to their own states and time periods. With only a few exceptions, previous research on tax effects reports only average effects: Mullen and Williams (1994) and Chernick (1997) check for (1) robustness across different time periods and (2) the effect of omitting some states from their samples. My analysis goes further by interacting tax variables with time, region, and state dummy variables to check for robustness across these dimensions.

The paper proceeds as follows. The second section derives a model of income growth that is general enough to encompass many of the models that have been used in previous research. The third section describes the data and discusses associated specification issues. The fourth section presents the initial empirical results. The fifth section checks for robustness across (1) alternative variable specifications, (2) alternative estimation procedures, (3) different time divisions of the data, and (4) different time periods, regions, and states. The sixth section pro- 
vides a possible explanation for why my study finds a robust relationship between taxes and income growth while previous studies have not. The seventh section concludes.

\section{A MODEL OF INCOME GROWTH}

I assume that state income $\left(Y_{t}\right)$ is determined by the following general version of the Cobb-Douglas production function,

$$
\text { [1] } Y_{t}=A_{t} K_{t}^{\alpha}\left(L_{t} Q_{t}\right)^{\beta}=A_{t} Q_{t}{ }^{\beta} K_{t}^{\alpha} L_{t}{ }^{\beta} \text {, }
$$

where $K_{t}$ and $L_{t}$ are capital and employment, $Q_{t}$ is the efficiency of labor, and $A_{t}$ represents other factors that influence state incomes (e.g., human capital variables, factor neutral productivity determinants). The textbook Solow model and the augmented human capital model of Mankiw et al. (1992) are both special cases of equation [1]. ${ }^{3}$

Dividing both sides by population, $N_{t^{\prime}}$ gives

[2] $\frac{Y_{t}}{N_{t}}=A_{t} Q_{t}^{\beta}\left(\frac{K_{t}}{N_{t}}\right)^{\alpha}\left(\frac{L_{t}}{N_{t}}\right)^{\beta} N_{t}^{(\alpha+\beta-1)}$.

This can be expressed in log form as

$$
\begin{aligned}
& \ln \left(y_{t}\right)=\alpha \ln \left(k_{t}\right)+\beta \ln \left(\ell_{t}\right) \\
& \quad+(\alpha+\beta-1) \ln \left(N_{t}\right)+\ln \left(A_{t}\right) \\
& \quad+\beta \ln \left(Q_{t}\right)
\end{aligned}
$$

where $y_{t}=Y_{t} / N_{t}, k_{t}=K_{t} / N_{t}$, and $\ell_{t}=$ $L / N_{\text {t }}$.

Differentiating equation [3] with respect to time yields
[4]

$$
\begin{aligned}
& \frac{\dot{y_{t}}}{y_{t}}=\alpha \frac{\dot{k_{t}}}{k_{t}}+\beta \frac{\dot{l}_{t}}{l_{t}}+(\alpha+\beta-1) \frac{\dot{N}_{t}}{N_{t}} \\
& +\left(\frac{\dot{A_{t}}}{A_{t}}+\beta \frac{\dot{Q_{t}}}{Q_{t}}\right) .
\end{aligned}
$$

It follows that

[5] $\ln \left(y_{t}\right)-\ln \left(y_{t-L}\right) \cong \alpha\left[\ln \left(k_{t}\right)\right.$

$$
\begin{aligned}
& \left.-\ln \left(k_{t-L}\right)\right]+\beta\left[\ln \left(l_{t}\right)-\ln \left(l_{t-L}\right)\right] \\
& +(\alpha+\beta-1)\left[\ln \left(N_{t}\right)-\ln \left(N_{t-L}\right)\right]+C_{t},
\end{aligned}
$$

where $C_{t}=\left[\ln \left(A_{t}\right)-\ln \left(A_{t-L}\right)\right]+\beta\left[\ln \left(Q_{t}\right)-\right.$ $\left.\ln \left(Q_{t-L}\right)\right]$ and $L=$ the length of the time period minus 1 (e.g., for a five-year period with $t$ measuring calendar years, $L=4){ }^{4}$

Equation [5] identifies changes in capital, employment, and population as important determinants of income growth. The last term, $C_{t}$, collects the additional effects of all other variables on income growth. Within this framework, taxes can affect economic growth via two channels. First, they can directly influence capital, employment, and population growth. Second, they can influence the way capital, labor and other resources are employed - either encouraging or discouraging their most productive employment.

\section{DATA AND ESTIMATION ISSUES}

My data consist of observations on 48 U.S. states from 1970-1999..$^{5}$ I decided on this particular time period because a longer time frame would have required me to omit many variables of interest. The respective 30 years of data are grouped

3 The textbook Solow model is $Y_{t}=K_{t}^{\alpha}\left(L_{t} Q_{t}\right)^{1-\alpha}=Q_{t}^{1-\alpha} K_{t}^{\alpha} L_{t}^{1-\alpha}$. Mankiw et al.'s augmented version of the Solow model is $Y_{t}=K_{t}^{\alpha} H_{t}^{\beta}\left(L_{t} Q_{t}\right)^{1-\alpha-\beta}=H_{t}^{\beta} Q_{t}^{1-\alpha-\beta} K_{t}^{\alpha} L_{t}^{1-\alpha-\beta}$, where $H$ represents human capital.

4 An alternative specification solves for the steady state value of $y$ as a function of exogenous parameters, and then introduces convergence through the inclusion of a lagged value of the dependent variable. The main cost of this approach is that it requires the imposition of additional restrictions.

5 Alaska and Hawaii were omitted, as is usual in studies of U.S. state economic growth. 
into six, five-year periods (1970-1974, 1975-1979, ... , 1995-1999). Data for most of these variables were collected from original data sources. ${ }^{6}$

Besides previously cited benefits, fiveyear interval data ${ }^{7}$ offer two additional advantages over annual data: they (1) minimize errors from misspecifying lag effects, and (2) reduce measurement error due to time-specification issues. The latter arise because data can have different start and end periods within a given calendar year. For example, state income data are defined over calendar years; state fiscal data are defined over fiscal years (which are different for different states); and other variables (e.g., employment, population data) may be measured at different points within the year (beginning/middle/end). In addition, a number of variables (e.g., variables based on decennial Census data) require annual interpolation in order to get a balanced panel. The errors associated with both types of time-specification issues are mitigated by using longer-interval data.

Following equation [5], the general specification for the empirical models is ${ }^{8}$

[6]

$$
\begin{aligned}
& D L N Y_{t}= \\
& {\left[\begin{array}{l}
\beta_{0}+\beta_{1} D L N K_{t}+\beta_{2} D L N L_{t}+\beta_{3} D L N N_{t} \\
+ \text { state fixed effects }+ \text { time fixed effects }
\end{array}\right]} \\
& +\sum_{d} \delta_{d}\left(X_{d, t}-X_{d, t-4}\right)+\sum_{l} \lambda_{l} X_{l, t-4}+\varepsilon_{t},
\end{aligned}
$$

where $t=1974,1979,1984,1989,1994,1999$; $D L N Y_{t}, D L N K_{t}, D L N L_{t}$, and $D L N N_{t}$ are the respective difference quantities from equation [5] multiplied by 100 (to give percent);
$\left(X_{d t}-X_{d, t-4}\right)$ is the change in the explanatory variable over the five-year period-where the subscript " $d$ " represents the "differenced" form of $X$; and $X_{l, t-4}$ is the value of the explanatory variable at the beginning of the five-year period-with subscript " $l$ " representing "level" form. Note that the last two terms can also be thought of as capturing the "contemporaneous" and "lagged" effects of $X .{ }^{9}$

A comparison of equations [5] and [6] reveals that both "differenced" and "level" forms of $X$ are used as proxies for $C_{t}=\left[\ln \left(A_{t}\right)-\ln \left(A_{t-L}\right)\right]+\beta\left[\ln \left(Q_{t}\right)-\ln \left(Q_{t-L}\right)\right]$. $C_{t}$ incorporates factors that affect the growth rate of productivity. As this term appears in differences, one may question why level forms of $X$ are included. Consider the role of education. It is likely that the stock of human capital (as distinct from the growth rate of human capital) is a determinant of the creation of new ideas, which contribute to productivity growth. This argues that level-measures of human capital, such as educational achievement, also be included as potential determinants of $C_{t}$. Similar arguments can be made for other variables. ${ }^{10}$

An alternative argument for including both "differenced" and "level" variables arises when these are seen as representing "contemporaneous" and "lagged" effects. For example, taxes may have immediate effects on the allocation of resources. They may also have persistent effects, as the effort to smooth adjustment costs causes tax-induced re-allocations of resources to be delayed into future time periods.

\footnotetext{
6 The Appendix presents statistical descriptions of all the variables used in this study.

7 The data are formatted in terms of five-year differences, not averages (cf. equation [5]).

8 I do not impose the restriction that $\beta_{3}=\left(\beta_{1}+\beta_{2}-1\right)$ because population growth could also be related to $C_{t^{\prime}}$ in which case the restriction would be violated.

9 For an alternative derivation that arrives at a virtually identical specification, see Bassanini, Scarpetta, and Hemmings (2001).

10 Previous studies of fiscal policy that specify income growth as the dependent variable have typically included either (1) level (cf. Helms, 1985; Chernick, 1997; Yamarick, 2000) or (2) differenced forms of the explanatory variables (cf. Evans and Karras, 1994; Garcia-Milá et al., 1996; Crain and Lee, 1999), but not both. Romans and Subrahmanyam (1979) and Mullen and Williams (1994) are the exceptions.
} 
As my measure of taxes, I use tax burden, defined as the ratio of state and local tax revenues to personal income. Tax burden is by far the most commonly employed measure of state taxation, and can be thought of as the "effective average tax rate" in a state (e.g., Helms, 1985; Mofidi and Stone, 1990; Mullen and Williams, 1994; Carroll and Wasylenko, 1994; Knight, 2000; Caplan, 2001; Yamarik, 2000, 2004; Alm and Rogers, 2005).

\section{INITIAL EMPIRICAL RESULTS}

Table 1 summarizes the initial results. The first column reports the results of estimating a narrowly specified version of equation [6]. The only explanatory variable from the set of differenced variables is the change in tax burden, TaxBurden(D); and the only explanatory variable from the set of level variables is the value of tax burden at the beginning of the period, TaxBurden $(L){ }^{11}$

Both tax variables are negative and highly significant (the $t$-values are -4.38 and -2.25 , respectively). This suggests that taxes have both an immediate and a persistent effect. The coefficient estimate for TaxBurden $(D)$ indicates that a one percentage-point increase in tax burden over a five-year period is associated with lower real Per Capita Personal Income (PCPI) growth of 1.37 percent during that period.

TABLE 1

ESTIMATION OF THE RELATIONSHIP BETWEEN TAX BURDEN AND INCOME GROWTH: INITIAL RESULTS

\begin{tabular}{|c|c|c|c|c|c|}
\hline & $\begin{array}{c}(1) \\
\text { Dep. } \\
\text { Variable = } \\
D L N Y\end{array}$ & $\begin{array}{c}(2) \\
\text { Dep. } \\
\text { Variable = } \\
\text { DLNK }\end{array}$ & $\begin{array}{c}(3) \\
\text { Dep. } \\
\text { Variable = } \\
\text { DLNL }\end{array}$ & $\begin{array}{c}(4) \\
\text { Dep. } \\
\text { Variable = } \\
D L N N\end{array}$ & $\begin{array}{c}(5) \\
\text { Dep. } \\
\text { Variable = } \\
D L N Y\end{array}$ \\
\hline DLNK & $\begin{array}{l}0.3304 \\
(7.26)\end{array}$ & - & - & - & - \\
\hline$D L N L$ & $\begin{array}{c}0.4258 \\
(6.70)\end{array}$ & - & - & - & - \\
\hline DLNN & $\begin{array}{c}0.4241 \\
(5.02)\end{array}$ & - & - & - & - \\
\hline TaxBurden(D) & $\begin{array}{c}-1.3660 \\
(-4.38)\end{array}$ & $\begin{array}{l}-2.5881 \\
(-2.43)\end{array}$ & $\begin{array}{c}-0.8380 \\
(-2.71)\end{array}$ & $\begin{array}{c}-0.0346 \\
(-0.13)\end{array}$ & $\begin{array}{c}-2.5925 \\
(-4.31)\end{array}$ \\
\hline TaxBurden $(L)$ & $\begin{array}{c}-0.8979 \\
(-2.25)\end{array}$ & $\begin{array}{c}-0.8318 \\
(-0.88)\end{array}$ & $\begin{array}{c}-0.3143 \\
(-0.85)\end{array}$ & $\begin{array}{l}-0.5907 \\
(-1.31)\end{array}$ & $\begin{array}{l}-1.5571 \\
(-2.15)\end{array}$ \\
\hline$R^{2}$ & 0.850 & 0.345 & 0.629 & 0.766 & 0.528 \\
\hline SIC & 729.84 & - & - & - & 1043.76 \\
\hline $\mathrm{AICc}$ & 815.28 & - & - & - & 1156.85 \\
\hline Observations & 288 & 288 & 288 & 288 & 288 \\
\hline $\begin{array}{l}\text { Hypothesis Tests } \\
\text { State effects }=0\end{array}$ & $\begin{array}{c}\chi^{2}=120.46 \\
(p-\text { value }=0.000)\end{array}$ & $\begin{array}{c}\chi^{2}=91.67 \\
(p-\text { value }=0.000)\end{array}$ & $\begin{array}{c}\chi^{2}=46.67 \\
(p-\text { value }=0.486)\end{array}$ & $\begin{array}{c}\chi^{2}=787.22 \\
(p-\text { value }=0.000)\end{array}$ & $\begin{array}{c}\chi^{2}=60.99 \\
(p-\text { value }=0.083)\end{array}$ \\
\hline Time effects $=0$ & $\begin{array}{c}\chi^{2}=86.76 \\
(p-\text { value }=0.000)\end{array}$ & $\begin{array}{c}\chi^{2}=90.93 \\
(p-\text { value }=0.000)\end{array}$ & $\begin{array}{c}\chi^{2}=301.00 \\
(p-\text { value }=0.000)\end{array}$ & $\begin{array}{c}\chi^{2}=54.68 \\
(p \text {-value }=0.000)\end{array}$ & $\begin{array}{c}\chi^{2}=194.79 \\
(p-\text { value }=0.000)\end{array}$ \\
\hline
\end{tabular}

Note: Coefficients are estimated using OLS. $t$-statistics are reported in parentheses and are calculated using White heteroscedasticity-robust standard errors. All equations include state and time fixed effects. AICc denotes the "corrected" version of the AIC. Summary statistics for each of the variables are reported in the Appendix.

11 A mathematically equivalent specification is to include the level of tax burden at the beginning and end of the period (times $t-4$ and $t$, respectively). 
A further consequence arises because this increase causes future periods to commence with a higher level of taxes. This lagged effect is measured by the coefficient on TaxBurden $(L)$ : A state having an initial tax burden that is one percentage point higher than other states is estimated to have real PCPI growth that is 0.90 percent lower in subsequent five-year periods.

Two points are worth noting. First, these effects represent the net effect of taxes and spending. Since expenditure variables are omitted from the specification, and since the relationship between U.S. state expenditures and revenues is generally one-to-one, the respective coefficients should be interpreted as an increase in taxes to fund general (unspecified) expenditures. ${ }^{12}$ Second, these estimated effects are sizeable. The mean value of the tax burden variable is 10.87 , and the mean growth rate of real PCPI (DLNY) is 8.23 percent. Thus, tax variable coefficients in the range of -1.0 represent economically important relationships.

With respect to the rest of the equation, the other coefficient estimates confirm the expected result that increases in a state's capital stock $(D L N K)$, employed labor force $(D L N L)$, and population (DLNN) are each associated with greater income growth. Overall, the equation has good explanatory power-a result that largely persists even when the state and time fixed effects are omitted. ${ }^{13}$

The estimated tax impacts of column 1 hold constant any effects that taxes might have on investment, employment, and population growth. One might reasonably expect taxes to be related to these as well. Columns 2-4 report the results of investigating this hypothesis by respectively regressing each of these on the two tax variables plus state and time fixed effects. Across all three equations, we see that higher taxes are associated with lower investment, lower employment growth, and lower population growth.

Notably, there are differences in the timing of the respective estimated effects. Columns 2 and 3 report that an increase in tax burden is associated with a statistically significant decrease in investment and employment growth during the same five-year period. Beyond that period, the tax effects are smaller and statistically insignificant. In contrast, column 4 indicates that an increase in tax burden is estimated to have a negligible contemporaneous effect on population growth. However, there is some evidence to indicate that higher taxes lower population growth in later time periods (the respective $p$-value is 0.19 ). These results are consistent with expectations about how taxes might affect each of these variables: investment and employment are more easily adjusted in the short-run, while migration decisions respond more slowly and require more time to be realized.

The preceding results suggest that taxes influence state income growth via two general channels. The first channel is associated with the term, $C_{t^{\prime}}$ which collects changes in the efficiency of labor $\left(Q_{t}\right)$ plus the effects of other time-varying factors related to productivity $\left(A_{t}\right)$. The second channel is via the terms DLNK, DLNL, and $D L N N$, which incorporate the effects of taxes on investment, employment, and

\footnotetext{
12 Many empirical growth studies follow Helms (1985) and include expenditures along with tax variables, with welfare expenditures as the omitted category. In contrast, my study—along with several others (e.g., Chernick, 1997; Tomljanovich, 2004) — does not. This affects the interpretation of the estimated tax effect. In the former case, the estimated tax effect represents the effect of raising tax revenues to fund welfare expenditures. In the latter case, the estimated effect represents the effect of raising tax revenues to fund general expenditures (assuming non-tax revenues and deficit remain constant). I prefer the latter specification because it represents the more relevant policy question. Further below, I investigate the consequences of including expenditure variables in the specification.

13 The $R^{2}$ value for the same specification without state and time fixed effects is 0.744 .
} 
population growth. Ideally, one could measure the combined effect of tax burden on income growth by estimating a structural system of equations with DLNY, $D L N K, D L N L$, and DLNN all treated as endogenous. Unfortunately, a lack of good instruments makes this approach unfeasible. ${ }^{14}$

An alternative is to estimate a reduced form version of column 1, omitting the terms DLNK, DLNL, and DLNN. The last column of Table 3 reports the results of this exercise. As expected, the combined effect of taxes is estimated to be substantially larger. A one percentage point increase in tax burden is associated with a contemporaneous decrease of 2.59 percent in real PCPI growth. In addition, future five-year growth rates are estimated to be lower by 1.56 percent.

\section{ROBUSTNESS CHECKS}

\section{Robustness with Respect to Alternative Specifications}

One concern with the previous set of results is that the estimated tax effects may suffer from omitted variable bias. Thus, it is important to control for the influence of other variables that may affect state income growth. The subsequent analysis takes the specification in column 1 of Table 1 as its starting point, and appends this with theoretically appropriate control variables.

It is clear from equation [5] that any number of variables could be included as proxies for the unobserved term, $C_{t}$. For example, Garcia-Milà and McGuire (1993) argue that a state's industrial's composition will matter if agglomeration economies or knowledge spillovers differ by industry. Ciccone and Hall (1996) hypothesize that the density of economic activity influences productivity due to externalities associated with physical proximity, among other reasons. Education and other demographic variables can proxy for productivity growth from human capital.

Reed (2008) identifies 32 variables that have been used or suggested by previous studies. Eliminating the public sector variables (such as categories of public spending or taxes) - since including these would change the nature of the tax variables-leaves 13 non-tax variables. These are identified in Table 2. Each of these can be argued to be included in differenced or level (initial value) form. If one also allows the initial value of income to be included as a regressor, ${ }^{15}$ and recalls that the differenced form of the population variable $(D L N N)$ is already included in the core specification, one obtains a total of 26 possible control variables. ${ }^{16}$

While it is likely that many of these variables do not really belong in the regression equation, it is not apparent $a$ priori which ones should be excluded. Choosing one or a few sets of control variables is potentially a problem, since previous literature (e.g., Leamer, 1985; Levine and Renelt, 1992; Crain and Lee, 1999; Sala-i-Martin

14 I estimated a model with lagged values of DLNK, DLNL, DLNN, and TaxBurden $(D)$ as instruments. This produced a positive, but insignificant coefficient for TaxBurden $(D)(p$-value $=0.758)$. However, I rejected this approach because the first-stage estimates indicated weak correlations. For example, the partial $F$ test for the excluded instruments in the TaxBurden $(D)$ equation was 0.77 , with a $p$-value of 0.511 . Further, some of the other estimated coefficients were implausible, such as the finding that employment growth $(D L N L)$ was associated with negative income growth.

15 Note that the interpretation of this variable should not be associated with convergence, since the model is not specified in steady-state form. Rather, this variable should be interpreted as proxying for the effect of omitted, initial-value variables that affect productivity growth.

16 The variable DLNN potentially affects income growth through two channels: (1) directly (cf. equation [5]), and (2) indirectly, through $C_{t}$. If $D L N N$ did not exert a separate effect via $C_{t}$, then its associated coefficient would be $\left(\beta_{1}+\beta_{2}-1\right)$ (cf. equations [5] and [6]). However, this hypothesis is consistently rejected in the subsequent empirical analyses. 
TABLE 2

LIST OF POTENTIAL CONTROL VARIABLES

\begin{tabular}{|c|c|c|}
\hline Variable & Description & $\begin{array}{c}\text { Selected Studies Which Have Used This } \\
\text { or a Related Variable }\end{array}$ \\
\hline Education & $\begin{array}{l}\text { Percent of population (aged } 25 \\
\text { and up) who have completed } \\
\text { college (source: Census) }\end{array}$ & $\begin{array}{l}\text { Wasylenko and McGuire (1985); Garcia-Milà } \\
\text { and McGuire (1992); Crown and Wheat (1995); } \\
\text { Phillips and Goss (1995); Dalenberg and } \\
\text { Partridge (1995); Partridge and Rickman (1996); } \\
\text { Clark and Murphy (1996); Ciccone and Hall } \\
\text { (1996); Crain and Lee (1999) }\end{array}$ \\
\hline Working population & $\begin{array}{l}\text { Percent of population between } \\
20 \text { and } 64 \text { years of age (source: } \\
\text { Census) }\end{array}$ & $\begin{array}{l}\text { Wasylenko and McGuire (1985); Mofidi and } \\
\text { Stone (1990); Dalenberg and Partridge (1995); } \\
\text { Crain and Lee (1999) }\end{array}$ \\
\hline Nonwhite & $\begin{array}{l}\text { Percent of population that is } \\
\text { nonwhite (source: Census) }\end{array}$ & $\begin{array}{l}\text { Mofidi and Stone (1990); Partridge and } \\
\text { Rickman (1996); Crain and Lee (1999) }\end{array}$ \\
\hline Female & $\begin{array}{l}\text { Percent of population that is } \\
\text { female (source: Census) }\end{array}$ & $\begin{array}{l}\text { Mofidi and Stone (1990); Partridge and } \\
\text { Rickman (1996); Clark and Murphy (1996) }\end{array}$ \\
\hline Population & $\begin{array}{l}\text { Log of total population } \\
\text { (source: Census) }\end{array}$ & Ciccone and Hall (1996); Alm and Rogers (2005) \\
\hline Population density & $\begin{array}{l}\text { Population density } \\
\text { (source: Census) }\end{array}$ & $\begin{array}{l}\text { Wasylenko and McGuire (1985); Carroll and } \\
\text { Wasyenko (1994); Clark and Murphy (1996); } \\
\text { Ciccone and Hall (1996); Crain and Lee (1999) }\end{array}$ \\
\hline Urban & $\begin{array}{l}\text { Percent of population living in } \\
\text { urban areas (source: Census) }\end{array}$ & $\begin{array}{l}\text { Holtz-Eakin (1993); Partridge and Rickman } \\
\text { (1996); Crain and Lee (1999) }\end{array}$ \\
\hline Agriculture & $\begin{array}{l}\text { Share of total earnings earned in } \\
\text { "Farm" and "Other Agriculture" } \\
\text { industries (source: BEA) }\end{array}$ & $\begin{array}{l}\text { Crown and Wheat (1995); Caselli and Coleman } \\
\text { (2001) }\end{array}$ \\
\hline Manufacturing & $\begin{array}{l}\text { Share of total earnings earned } \\
\text { in "Manufacturing" industries } \\
\text { (source: BEA) }\end{array}$ & $\begin{array}{l}\text { Crown and Wheat (1995); Crain and Lee (1999); } \\
\text { Caselli and Coleman (2001); Stansel (2005) }\end{array}$ \\
\hline Service & $\begin{array}{l}\text { Share of total earnings earned } \\
\text { in "Service" industries (source: } \\
\text { BEA) }\end{array}$ & Clark and Murphy (1996) \\
\hline Mining & $\begin{array}{l}\text { Share of total earnings earned } \\
\text { in "Mining" industries (source: } \\
\text { BEA) }\end{array}$ & $\begin{array}{l}\text { Holtz-Eakin (1993); Crown and Wheat (1995); } \\
\text { Clark and Murphy (1996); Mitchener and } \\
\text { McLean (2003) }\end{array}$ \\
\hline Union & $\begin{array}{l}\text { Percent of nonagricultural wage } \\
\text { and salary employees who are } \\
\text { union members (source: Hirsch, } \\
\text { McPherson, and Vroman, 2001) }\end{array}$ & $\begin{array}{l}\text { Plaut and Pluta (1983); Mofidi and Stone (1990); } \\
\text { Dalenberg and Partridge (1995); Phillips and } \\
\text { Goss (1995); Partridge and Rickman (1996); } \\
\text { Clark and Murphy (1996) }\end{array}$ \\
\hline Diversity & $\begin{array}{l}\text { A measure of industrial diversity, } \\
\text { Diversity }=\sum_{i}\left(\frac{\text { Earnings in Industry }}{\text { Total Earnings }}\right)^{2} \\
\text { (source: BEA) }\end{array}$ & $\begin{array}{l}\text { Mofidi and Stone (1990); Garcia-Milà and } \\
\text { McGuire (1993); Partridge and Rickman (1996); } \\
\text { Crain and Lee (1999) }\end{array}$ \\
\hline
\end{tabular}

Note: This table is excerpted from Reed (2008). 
et al., 2004) has shown that estimated coefficients are often fragile, sensitive to the particular composition of conditioning variables.

The problem is complicated by the fact that there are $2^{26} \cong 67$ million ways to combine 26 variables, each one a possible regression specification. I address the issue of variable specification in the following way. First, I estimate a complete specification that includes all 26 variables. Next, I identify and estimate the "best" specifications as determined by two different model selection criteria, the Schwarz Information Criterion (SIC) and the corrected Akaike Information Criterion (AICc). ${ }^{17}$ This produces three sets of regression results, each of which is reported in Table 3.

Of greatest interest are the first two rows of Table 3 . These report the estimated coefficients of TaxBurden(D) and TaxBurden $(L)$ after including alternative sets of control variables. Both tax coefficients are smaller in absolute value compared to column 1 of Table 1, where the estimated values are -1.37 and -0.90 , respectively. Nevertheless, they remain negative across all the expanded specifications of Table 3. Further, they continue to be highly significant. In the "All Variables" specification, TaxBurden(D) and TaxBurden $(L)$ have $t$-statistics ( $p$-values) of, respectively, $-2.58(0.011)$ and -2.87(0.004). The corresponding $t$-statistics are even higher in the "Best SIC" and "Best AICc" specifications. And while these latter two specifications are the product of sequential search, the $t$-statistics / $p$-values for the two tax variables can still be interpreted in the classical manner because the search procedure includes these two variables in every specification.
Turning to the other variables, I find that the estimated coefficients are generally consistent with the predictions of growth theory, or at least not inconsistent. Focusing on the coefficients from column 2 of Table 3-the "Best SIC Specification"-we observe the following results (ignoring the distinction between initial levels and contemporaneous changes): higher educational attainment, a greater percentage of the population who are of working age, a greater percentage of the population that is nonwhite, a larger population, a greater reliance on agriculture, and a more unionized workforce are associated with higher income growth. A larger female population, a larger mining sector, and greater industrial diversity are associated with lower income growth. Lastly, ceteris paribus, states with a greater initial value of real PCPI grow slower than other states.

In conclusion, I find that the significant, negative tax effects first reported in column 1 of Table 1 are robust to the inclusion of a wide variety of control variables. ${ }^{18}$ The next section investigates the robustness of the relationship between tax burden and state income growth when alternative estimation procedures are employed.

\section{Robustness with Respect to Alternative Estimation Procedures}

The subsequent analysis employs the variable specification of column 2 of Table 3 for additional robustness checks. This OLS equation displays good properties. It has a high $R^{2}$, the key explanatory variables all have large $t$-statistics, the Durbin-Watson statistic is close to two, and a test of error normality fails to be rejected at the five percent level. ${ }^{19}$

\footnotetext{
17 These criteria, as well as the associated SAS/IML computer program that implements them, are described in further detail in Reed (2008).

18 I also included squared terms for the two tax variables, to allow for nonlinear tax effects. These are jointly significant. Both estimated tax effects were monotonically negative for all observations within the sample range, except for the largest value of the TaxBurden $(D)$ variable.

19 The Durbin-Watson statistic is 2.15; the Jarque-Bera statistic is 5.07, with an associated $p$-value of 0.079 .
} 
TABLE 3

ROBUSTNESS CHECK ACROSS ALTERNATIVE SPECIFICATIONS

\begin{tabular}{|c|c|c|c|c|}
\hline Variable Name $^{1}$ & $\mathrm{D} / \mathrm{L}$ & $\begin{array}{c}(1) \\
\text { All Variables }\end{array}$ & $\begin{array}{c}(2) \\
\text { Best SIC Specification }\end{array}$ & $\begin{array}{c}\text { (3) } \\
\text { Best AICc Specification }\end{array}$ \\
\hline \multirow[t]{2}{*}{ Tax burden } & $\mathrm{D}$ & $\begin{array}{c}-0.4240 \\
(-2.58)\end{array}$ & $\begin{array}{l}-0.5470 \\
(-3.59)\end{array}$ & $\begin{array}{l}-0.5368 \\
(-3.36)\end{array}$ \\
\hline & $\mathrm{L}$ & $\begin{array}{l}-0.5838 \\
(-2.87)\end{array}$ & $\begin{array}{l}-0.6905 \\
(-3.20)\end{array}$ & $\begin{array}{l}-0.7045 \\
(-3.39)\end{array}$ \\
\hline \multirow[t]{2}{*}{ Education } & $\mathrm{D}$ & $\begin{array}{l}1.2504 \\
(1.99)\end{array}$ & $\begin{array}{l}1.4766 \\
(2.44)\end{array}$ & $\begin{array}{l}1.1673 \\
(2.00)\end{array}$ \\
\hline & $\mathrm{L}$ & $\begin{array}{l}1.2759 \\
(6.84)\end{array}$ & $\begin{array}{l}1.1221 \\
(8.65)\end{array}$ & $\begin{array}{l}1.2004 \\
(7.06)\end{array}$ \\
\hline \multirow[t]{2}{*}{ Working population } & $\mathrm{D}$ & $\begin{array}{l}1.3235 \\
(3.51)\end{array}$ & $\begin{array}{l}1.6503 \\
(4.75)\end{array}$ & $\begin{array}{l}1.3508 \\
(4.21)\end{array}$ \\
\hline & $\mathrm{L}$ & $\begin{array}{l}0.9789 \\
(4.42)\end{array}$ & $\begin{array}{l}1.1264 \\
(5.66)\end{array}$ & $\begin{array}{l}1.0405 \\
(4.89)\end{array}$ \\
\hline \multirow[t]{2}{*}{ Nonwhite } & $\mathrm{D}$ & $\begin{array}{l}1.1447 \\
(2.27)\end{array}$ & $\begin{array}{l}1.2900 \\
(2.87)\end{array}$ & $\begin{array}{l}1.0064 \\
(2.20)\end{array}$ \\
\hline & $\mathrm{L}$ & $\begin{array}{c}-0.2699 \\
(-1.77)\end{array}$ & - & $\begin{array}{c}-0.3633 \\
(-2.83)\end{array}$ \\
\hline \multirow[t]{2}{*}{ Female } & $\mathrm{D}$ & $\begin{array}{l}-2.7097 \\
(-1.97)\end{array}$ & $\begin{array}{c}-3.4947 \\
(-2.92)\end{array}$ & $\begin{array}{l}-3.4630 \\
(-2.92)\end{array}$ \\
\hline & $\mathrm{L}$ & $\begin{array}{l}0.3608 \\
(0.46)\end{array}$ & - & - \\
\hline Population & $\mathrm{L}$ & $\begin{array}{c}2.8954 \\
(1.50)\end{array}$ & $\begin{array}{l}4.0213 \\
(3.19)\end{array}$ & - \\
\hline \multirow[t]{2}{*}{ Population density } & $\mathrm{D}$ & $\begin{array}{c}0.0300 \\
(0.74)\end{array}$ & - & - \\
\hline & $\mathrm{L}$ & $\begin{array}{l}0.0217 \\
(1.64)\end{array}$ & - & $\begin{array}{c}0.0269 \\
(2.39)\end{array}$ \\
\hline \multirow[t]{2}{*}{ Urban } & $\mathrm{D}$ & $\begin{array}{l}-0.1486 \\
(-1.32)\end{array}$ & - & - \\
\hline & $\mathrm{L}$ & $\begin{array}{c}-0.0674 \\
(-0.94)\end{array}$ & - & - \\
\hline \multirow[t]{2}{*}{ Agriculture } & $\mathrm{D}$ & $\begin{array}{c}0.5333 \\
(4.19)\end{array}$ & $\begin{array}{l}0.5365 \\
(5.82)\end{array}$ & $\begin{array}{l}0.5272 \\
(5.08)\end{array}$ \\
\hline & $\mathrm{L}$ & $\begin{array}{l}0.3413 \\
(3.03)\end{array}$ & $\begin{array}{l}0.3881 \\
(5.54)\end{array}$ & $\begin{array}{l}0.4084 \\
(6.03)\end{array}$ \\
\hline \multirow[t]{2}{*}{ Manufacturing } & $\mathrm{D}$ & $\begin{array}{l}-0.0218 \\
(-0.13)\end{array}$ & - & - \\
\hline & $\mathrm{L}$ & $\begin{array}{l}-0.0304 \\
(-0.25)\end{array}$ & - & - \\
\hline \multirow[t]{2}{*}{ Service } & $\mathrm{D}$ & $\begin{array}{l}0.0397 \\
(0.16)\end{array}$ & - & - \\
\hline & $\mathrm{L}$ & $\begin{array}{l}-0.3083 \\
(-1.90)\end{array}$ & - & $\begin{array}{l}-0.2956 \\
(-2.57)\end{array}$ \\
\hline \multirow[t]{2}{*}{ Mining } & $\mathrm{D}$ & $\begin{array}{l}-0.6314 \\
(-2.72)\end{array}$ & $\begin{array}{l}-0.5724 \\
(-2.95)\end{array}$ & $\begin{array}{l}-0.5032 \\
(-2.50)\end{array}$ \\
\hline & $\mathrm{L}$ & $\begin{array}{l}-0.3006 \\
(-1.58)\end{array}$ & - & - \\
\hline \multirow[t]{2}{*}{ Union } & $\mathrm{D}$ & $\begin{array}{l}0.1240 \\
(1.86)\end{array}$ & $\begin{array}{c}0.1143 \\
(2.10)\end{array}$ & $\begin{array}{c}0.1251 \\
(2.37)\end{array}$ \\
\hline & $\mathrm{L}$ & $\begin{array}{l}0.0182 \\
(0.27)\end{array}$ & - & - \\
\hline \multirow[t]{2}{*}{ Diversity } & $\mathrm{D}$ & $\begin{array}{l}0.2591 \\
(1.00)\end{array}$ & - & $\begin{array}{l}0.3241 \\
(1.57)\end{array}$ \\
\hline & $\mathrm{L}$ & $\begin{array}{l}-0.2144 \\
(-1.02)\end{array}$ & $\begin{array}{c}-0.3495 \\
(-2.26)\end{array}$ & - \\
\hline$L N Y_{-} \_1$ & & $\begin{array}{l}-41.857 \\
(-8.37)\end{array}$ & $\begin{array}{l}-39.783 \\
(-9.72)\end{array}$ & $\begin{array}{l}-44.085 \\
(-9.96)\end{array}$ \\
\hline Number of observations & & 288 & 288 & 288 \\
\hline$R^{2}$ & & 0.938 & 0.933 & 0.935 \\
\hline SIC & & 624.70 & 572.52 & 573.91 \\
\hline $\mathrm{AICc}$ & & 675.36 & 647.78 & 645.00 \\
\hline
\end{tabular}

${ }^{1}$ Summary statistics for each of the variables is reported in the Appendix.

Note: The regression equation follows the general specification of equation [6] in the text. " $D$ " and " $L$ " stand for differenced and level forms of the variables. In addition to the variables listed above, the model includes the variables $D L N K, D L N L, D L N N$, and state and time fixed effects. $t$-statistics are listed in parenthesis below each estimated coefficient and are calculated using White heteroscedasticity-robust standard errors. 
However, there are at least two concerns. First, panel data are often characterized by complex error structures. Using the residuals from this specification, I tested for (1) first-order serial correlation, (2) groupwise heteroscedasticity, and (3) cross-sectional correlation. I found no evidence of significant serial correlation (the estimated value of the $\mathrm{AR}(1)$ parameter was -0.02). However, I reject the hypothesis of no groupwise heteroscedasticity ${ }^{20}$ and find substantial evidence of cross-sectional correlation. ${ }^{21}$ This raises worries about the inefficiency of the coefficient estimates and biasedness in the estimates of the standard errors. ${ }^{22}$

Unfortunately, while one can estimate an error variance-covariance matrix that allows for cross-sectional correlation, one cannot invert that matrix, since $N=48>T$ $=6$. This precludes the use of Parks-type, feasible FGLS. However, there are several alternatives. One approach is to continue to use OLS, but adjust the standard errors for cross-sectional correlation; either by using Beck and Katz's "panel-corrected standard error" procedure (Beck and Katz, 1995), or by using a more robust estimator of the error variance-covariance matrix. Another is to follow-up a suggestion by Greene (2003, cf 333f) and use FGLS, weighting on groupwise heteroscedasticity while adjusting the standard errors for cross-sectional correlation. Accordingly, I check for robustness of the estimated tax effects across the following alternative estimation procedures.

1. OLS with panel-corrected standard errors.

2. OLS with heteroscedasticity and cross-sectional correlation robust standard errors.

3. FGLS (weighted on groupwise heteroscedasticity) with heteroscedasticity robust standard errors.

4. FGLS (weighted on groupwise heteroscedasticity) with panel-corrected standard errors.

5. FGLS (weighted on groupwise heteroscedasticity) with heteroscedasticity and cross-sectional correlation robust standard errors.

There is an additional concern. The explanatory variables include both fixed effects and a lagged form of the dependent variable as explanatory variables. This generates correlation between the error term and the lagged form of the dependent variable, causing biased coefficient estimates (Nickell, 1981). To address this concern, I use two DPD estimators: the Arellano-Bond (difference) one-step and two-step procedures. ${ }^{23}$

Table 4 reports the estimates from these alternative estimation procedures. For comparison's sake, the first row duplicates

${ }^{20}$ I use the modified Wald test for groupwise heteroscedasticity available in the STATA command xttest3. The corresponding sample Chi-square value is 798.30 with 48 degrees of freedom, and the associated $p$-value is 0.0000 .

${ }^{21}$ I use Pesaran's test for cross-sectional dependence available in the STATA command xtcsd, which is distributed asymptotically standard normal. The corresponding cross-sectional dependence (CD) statistic is -1.481 with a $p$-value of 0.1385 . However, this test assumes that the cross-sectional correlations are all same-signed. It has low power when the cross-sectional correlations are not same-signed, which describes my data. The average, absolute value of the cross-sectional correlations is 0.375 even with the inclusion of time fixed effects. This is quite large. Accordingly, I correct some of my estimates for cross-sectional correlation even though I do not formally reject the null hypothesis of no cross-sectional dependence.

22 Note that "White standard errors" are robust only to heteroscedasticity, and not cross-sectional correlation.

23 The DPD estimates were obtained using STATA's xtabond2 procedure. Note that both the one-step and two-step procedures assume no cross-sectional correlation. I do not use the DPD (system) estimator because the key moment condition in the level equation requires that the "distance" between a state's initial income and its "steady-state" value be uncorrelated with the state fixed effect (cf. Roodman, 2006, page 27). This is clearly violated in endogenous growth models and likely violated in exogenous growth models. 
TABLE 4

ROBUSTNESS CHECK USING ALTERNATIVE ESTIMATION PROCEDURES

\begin{tabular}{lcc}
\hline Procedure & TaxBurden $(D)$ & TaxBurden $(L)$ \\
\hline OLS & $-\mathbf{0 . 5 4 7 0}$ & $-\mathbf{0 . 6 9 0 5}$ \\
with robust VCE for heteroscedasticity & $(-3.59)$ & $(-3.20)$ \\
with panel-corrected standard errors & $(-2.88)$ & $(-3.35)$ \\
with robust VCE for heteroscedasticity and cross-sectional correlation & $(-5.43)$ & $(-6.57)$ \\
& & $-\mathbf{0 . 6 4 9 4}$ \\
FGLS (weighted on groupwise heteroscedasticity) & $(-3.83)$ & $(-3.89)$ \\
with robust VCE for heteroscedasticity & $(-3.52)$ & $(-4.43)$ \\
with panel-corrected standard errors & $(-3.54)$ & $(-8.00)$ \\
with robust VCE for heteroscedasticity and cross-sectional correlation & & $-\mathbf{0 . 8 5 4 7}$ \\
DPD (difference) & $-\mathbf{0 . 6 8 3 4}$ & $(-3.67)$ \\
Arellano-Bond one-step procedure & $(-3.65)$ & $-\mathbf{0 . 7 6 8 4}$ \\
DPD (difference) & $-\mathbf{0 . 5 3 4 1}$ & $(-2.16)$ \\
Arellano-Bond two-step procedure & $(-1.74)$ & $\mathbf{3}$
\end{tabular}

Note: Coefficient estimates are boldface; $t$-statistics are reported in parentheses. Each estimation procedure estimates the same variable specification as column 2 of Table 3 . The first set of OLS results repeats those results for comparison's sake. The respective estimation procedures are described in greater detail in the fourth section.

the tax coefficient estimates from column (2), Table 3. There are two main findings from this analysis: Both FGLS and DPD confirm earlier results in that they produce negative coefficient estimates for each of the tax variables. The FGLS estimates are similar in size to the OLS estimates, while the DPD estimates are generally larger (in absolute value). In addition, the statistical significance of the tax effects is confirmed across all alternative estimation procedures. Of the $16 t$-statistics reported in Table 4, 14 imply significance at the one percent level, with the remaining two significant at the five and ten percent levels. Accordingly, I conclude that my main findings of negative, statistically significant tax effects are robust across alternative estimation procedures.

\section{Robustness across Alternative Cuts of the Data}

The preceding analyses divide the 30 years of data from 1970-1999 into six periods of five-years each: 1970-1974, 1975$1979, \ldots, 1995-1999$. This section looks at two alternative ways of dividing the data.
The first approach allows the endpoint of one five-year period to coincide with the beginning of the next five-year period. Following this approach, the data are divided as follows: 1970-1975, 1975-1980, 1980-1985, ..., 1995-2000. A drawback of this approach is that it forces dependency between contiguous time periods. An alternative approach keeps the endpoints and beginning points of the periods separate, but shifts the data by a year: 1971-1975, 1976-1980, ..., 1996-2000.

This analysis takes its starting point as the variable specification of column 2 , Table 3, estimated with FGLS (weighting on groupwise heteroscedasticity) using robust Variance-Covariance Estimation (VCE) to address heteroscedasticity and cross-sectional correlation. ${ }^{24}$ These results were previously reported in abbreviated form in Table 4 and are repeated in column 1 of Table 5. The subsequent two columns use the same variable specification and estimation procedure, but employ different cuts of the data.

Alternative cuts of the data can make a difference. For example, the estimates for Female(D) change considerably, with the

\footnotetext{
${ }^{24}$ I chose this estimation procedure given that testing of the residuals produced evidence of groupwise heteroscedasticity and cross-sectional correlation.
} 
TABLE 5

ROBUSTNESS CHECK USING ALTERNATIVE CUTS OF THE DATA

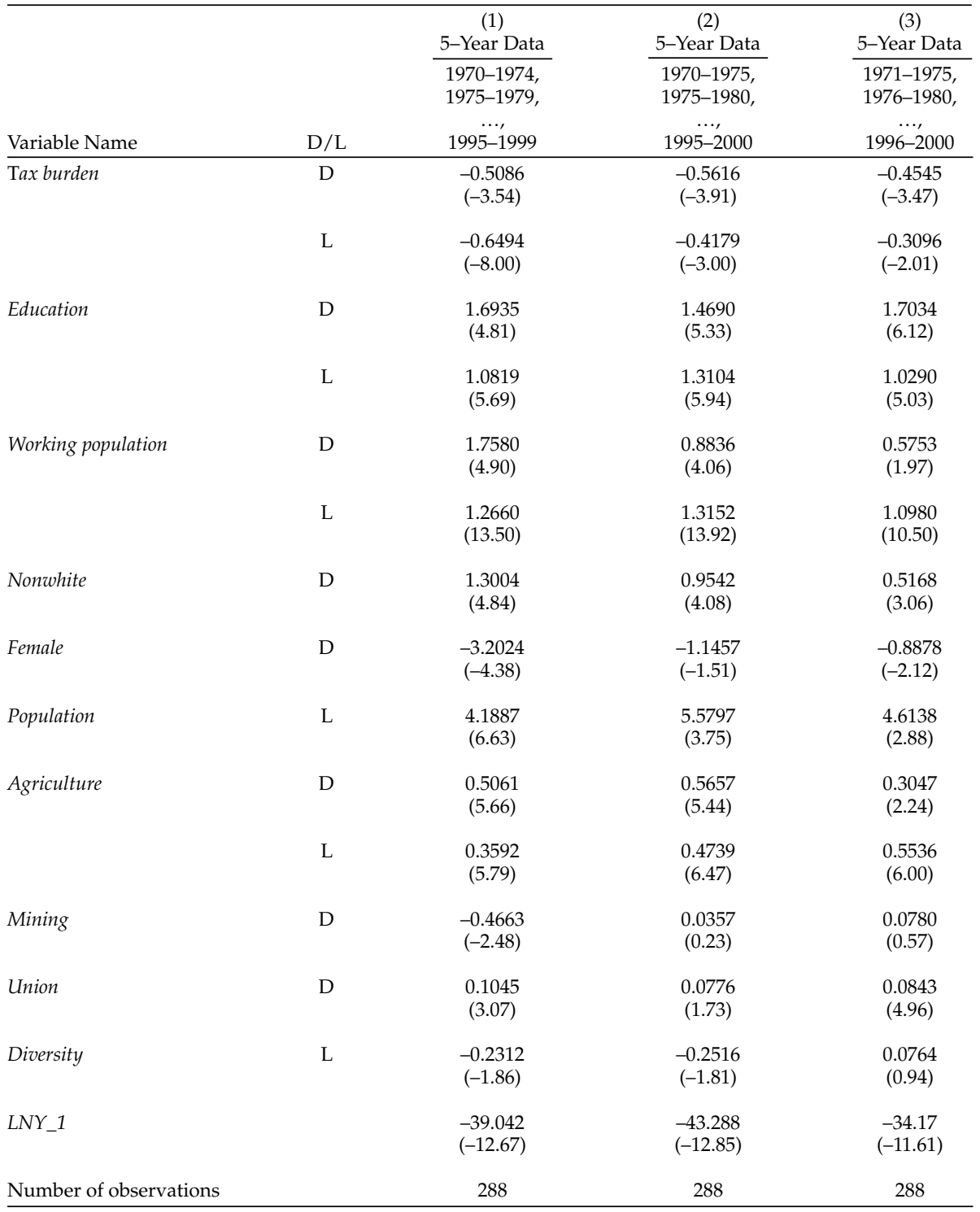

Note: Each of the three sets of regression results employs FGLS (weighting on groupwise heteroscedasticity) with robust VCE for heteroscedasticity and cross-sectional correlation. $t$-statistics are reported in parentheses below the respective coefficient estimates. The first column reproduces previous results for comparison's sake (cf. third row from bottom in Table 4). The next two columns show the effects of using different cuts of the data. 
respective $t$-values ranging from -4.38 to -1.51 . The coefficients for $\operatorname{Mining}(D)$ and Diversity $(L)$ also show substantial variation, even switching signs. Indeed, the coefficient for TaxBurden $(L)$ in column 3 is less than one-half the size of the equivalent estimate in column 1 , with a correspondingly large change in the respective $t$-statistic.

Nevertheless, these estimates provide overall confirmation of the previous tax burden results. Across the alternative time divisions of the data, the coefficients of the two tax variables are uniformly, negatively signed and statistically significant, always having a $t$-statistic larger than two in absolute value.

\section{Robustness across Time Periods, Regions, and States}

A possible concern with previous estimates is that the results may be driven by a few time periods, regions, or states with particularly strong relationships between tax burden and income growth, and that these may not be broadly representative for the majority of observations. Previous specifications assumed that the estimated tax effects were the same for all observations. In this section, I use interaction terms to estimate individual time period, region, and state effects.
I first check for robustness across time periods. There are a total of six five-year periods: 1970-1974, 1975-1979, 1980-1984, 1985-1989, 1990-1994, 1995-1999. The variable specification for this analysis continues to use the "Best SIC Specification" from Table 3, but supplements it with time-interaction effects to capture changes in the tax burden/income growth relationship over time. Following the previous results on estimation procedures, all coefficients are estimated using FGLS (with weighting for groupwise heteroscedasticity), with a White robust estimator for heteroscedasticity and cross-sectional correlation used to calculate standard errors. I first estimate time-specific coefficients for the variable TaxBurden(D). I then repeat the robustness check by estimating time-specification coefficients for the variable TaxBurden $(L)$.

Table 6 summarizes the results. Notably, each of the 12 time-specific coefficients is negative. Ten of the 12 are individually significant. While the pattern is not perfect, smaller estimated coefficients for TaxBurden $(D)$ are generally accompanied by larger coefficients for TaxBurden (L), and vice versa. ${ }^{25} \mathrm{~A}$ similar pattern is observed when I estimate region-and state-specific interaction terms. An interpretation consistent with these results is that changes in tax burden take longer to register their

TABLE 6

ROBUSTNESS CHECK ACROSS TIME PERIODS

\begin{tabular}{lcccc}
\hline & \multicolumn{3}{c}{ Time-Specific Coefficients } \\
\cline { 2 - 5 } Time Period & \multicolumn{2}{c}{ TaxBurden(D) } & \multicolumn{2}{c}{ TaxBurden $(L)$} \\
\cline { 2 - 3 } \cline { 2 - 4 } Coefficient & t-statistic & & Coefficient & $t$-statistic \\
\hline $1970-1974$ & -1.1551 & -9.83 & -0.3062 & -5.18 \\
$1975-1979$ & -0.7518 & -4.58 & -0.6710 & -7.32 \\
$1980-1984$ & -0.0615 & -0.24 & -0.6455 & -7.18 \\
$1985-1989$ & -0.1642 & -0.71 & -0.9044 & -6.61 \\
$1990-1994$ & -0.6450 & -2.97 & -1.0086 & -8.20 \\
\hline
\end{tabular}

Note: Regression results are derived from a regression equation having the variable specification of column 2 of Table 3, supplemented with the respective time-interaction dummy variables (cf. the text for further details). The estimation procedure is FGLS (weighting on groupwise heteroscedasticity) with robust VCE for heteroscedasticity and cross-sectional correlation.

25 The smaller estimated coefficients for TaxBurden(D) during the 1980s is consistent with the findings of Carroll and Wasylenko (1994), though their study focused on state employment. 
effects for some time periods, regions, and states. That being said, the main finding from Table 6 is that the estimated relationships between income growth, and both the differenced and level forms of tax burden, are negative for every time period.

Table 7 reports the results of a similar analysis checking for robustness across the eight BEA regions and 48 states. The top part of the table reports the results of the regional analysis: 15 of the 16 estimated tax effects are negative; ten are significant at the ten percent level. The bottom part of the table reports a summary analysis for the states: Of the 48, state-specific coefficients for TaxBurden(D), 72.9 percent are negative. Of these, 15 are statistically significant at the ten percent level, and 13 of these are negative (86.7 percent). The corresponding numbers for the TaxBurden $(L)$ coefficients are 64.5 and 69.2 percent, respectively. Only two states (Montana and Virginia) have positive coefficients for both TaxBurden(D) and TaxBurden $(L)$, and none of the associated coefficients are significant at the ten percent level. In contrast, 20 states have negative coefficients for both tax variables. In 11 of these cases, at least one of the tax coefficients is significant at the ten percent level.

The results of Table 7 are not as robust as those of Table 6 . In general, I find that as the data are cut into finer slices, the results become less consistent. By the time I get to the state level, there are only six observations per estimated coefficient (compared to 48 observations for the time-period analyses). ${ }^{26}$ Nevertheless, it is clear that the finding of negative and statistically significant tax effects applies widely across time periods, regions, and states; and is not driven by a few observations exerting a disproportionately strong influence.

TABLE 7

ROBUSTNESS CHECK ACROSS BEA REGIONS AND STATES

\begin{tabular}{|c|c|c|c|c|}
\hline & \multicolumn{2}{|c|}{ TaxBurden $(D)$} & \multicolumn{2}{|c|}{ TaxBurden $(L)$} \\
\hline & Coefficient & t-statistic & Coefficient & t-statistic \\
\hline \multicolumn{5}{|l|}{ Region-Specific Coefficients: } \\
\hline Great Lakes & -0.2226 & -0.36 & -0.5268 & -1.79 \\
\hline Mid-Atlantic & -0.6228 & -1.97 & -0.4599 & -1.90 \\
\hline New England & -0.5956 & -1.58 & -0.7789 & -2.13 \\
\hline Plains & -0.7237 & -2.15 & -0.2635 & -2.16 \\
\hline Rocky Mountain & -0.3329 & -2.22 & -1.1408 & -3.39 \\
\hline South & -0.5232 & -2.29 & -0.4521 & -1.28 \\
\hline Southwest & -1.2132 & -1.68 & 0.4150 & 0.87 \\
\hline West & -0.7435 & -2.49 & -0.0570 & -0.10 \\
\hline \multicolumn{5}{|l|}{ State-Specific Coefficients: } \\
\hline \multicolumn{2}{|l|}{$\begin{array}{l}\text { Total number of coefficients/Number negative } \\
\text { (Percent negative) }\end{array}$} & $\begin{array}{l}48 / 35 \\
(72.9)\end{array}$ & \multicolumn{2}{|c|}{$\begin{array}{l}48 / 31 \\
(64.5)\end{array}$} \\
\hline \multicolumn{2}{|c|}{$\begin{array}{l}\text { Total number of significant coefficients/Number negative } \\
\text { (Percent negative) }\end{array}$} & 13 & \multicolumn{2}{|c|}{$\begin{array}{l}13 / 9 \\
(69.2)\end{array}$} \\
\hline
\end{tabular}

Note: Regression results are derived from a regression equation having the variable specification of column 2 of Table 3, supplemented with the respective interaction dummy variables (cf. the text for further details). The estimation procedure is FGLS (weighting on groupwise heteroscedasticity) with robust VCE for heteroscedasticity and cross-sectional correlation. For the last row, statistical significance is defined at the 10 percent level.

26 An alternative approach that estimates individual state effects without a great sacrifice in degrees of freedom is to include squared terms for both tax variables. This allows taxes to exert either positive or negative effects on income growth, depending on the value of the respective tax variable. When I did this, I found that the individual, state-specific tax effects were negative for every state for both tax variables, except for one state with a large outlier value for the TaxBurden[D] variable. I thank a referee for suggesting this approach. 


\section{Robustness across Alternative Specifications of Government Finances}

As Helms (1985) points out, the government budget constraint should always be kept in mind when interpreting the coefficients of fiscal variables:

$$
\begin{aligned}
& \text { (Tax Revenues + Non-Tax Revenues) } \\
& \quad \text { - (Welfare Expenditures } \\
& + \text { "Productive Expenditures") } \\
& + \text { Deficit }=0
\end{aligned}
$$

where I define "Productive Expenditures" as all state and local Direct General Expenditures other than Public Welfare. Thus, an increase in taxes must be accompanied by some combination of (1) a decrease in Non-Tax Revenues (e.g., fees and federal aid), (2) an increase in Welfare Expenditures or Productive Expenditures, and (3) a decrease in the Deficit. Previous specifications did not attempt to distinguish these alternatives.

Table 8 reports the results of including variables for both differences and levels of Non-Tax Revenues and Welfare, appropriately divided by state Personal Income. In column 2, the coefficients on the tax variables should now be interpreted as estimating the effect of an increase in taxes matched by a corresponding increase in general expenditures (as a practical matter, we can ignore deficits as they are usually negligibly small compared to overall revenues and expenditures.) The tax coefficients remain negative and statistically significant.

Column 3 adds welfare variables to the specification. The tax coefficients in this specification should be interpreted as estimating the effect of an increase in taxes matched by a corresponding increase in Productive Expenditures. Again, the estimated coefficients remain negative and statistically significant. Column 4 removes the Non-Tax Revenue variables from the specification, with no change in the overall finding of negative and statistically significant tax

\begin{tabular}{|c|c|c|c|c|}
\hline & Only Taxes & $\begin{array}{c}(2) \\
\text { Taxes }+ \\
\text { Non-Tax Revenues }\end{array}$ & $\begin{array}{c}\text { (3) } \\
\text { Taxes }+ \\
\text { Non-Tax Revenues }+ \\
\text { Welfare Expenditures }\end{array}$ & $\begin{array}{c}\text { (4) } \\
\text { Taxes }+ \\
\text { Welfare Expenditures }\end{array}$ \\
\hline TaxBurden(D) & $\begin{array}{c}-0.5086 \\
(-3.54)\end{array}$ & $\begin{array}{c}-0.4020 \\
(-2.82)\end{array}$ & $\begin{array}{c}-0.4654 \\
(-2.58)\end{array}$ & $\begin{array}{c}-0.5622 \\
(-3.45)\end{array}$ \\
\hline TaxBurden $(L)$ & $\begin{array}{c}-0.6494 \\
(-8.00)\end{array}$ & $\begin{array}{c}-0.4866 \\
(-7.63)\end{array}$ & $\begin{array}{c}-0.5913 \\
(-7.38)\end{array}$ & $\begin{array}{c}-0.7277 \\
(-8.13)\end{array}$ \\
\hline NonTaxRevenues(D) & - & $\begin{array}{c}-0.3763 \\
(-2.98)\end{array}$ & $\begin{array}{c}-0.4306 \\
(-3.36)\end{array}$ & - \\
\hline NonTaxRevenues $(L)$ & - & $\begin{array}{c}-0.3784 \\
(-3.39)\end{array}$ & $\begin{array}{c}-0.4375 \\
(-2.94)\end{array}$ & - \\
\hline Welfare (D) & - & - & $\begin{array}{l}0.6157 \\
(3.49)\end{array}$ & $\begin{array}{c}0.5131 \\
(3.14)\end{array}$ \\
\hline Welfare $(L)$ & - & - & $\begin{array}{c}0.5749 \\
(1.84)\end{array}$ & $\begin{array}{c}0.3482 \\
(1.29)\end{array}$ \\
\hline
\end{tabular}
effects.

TABLE 8

ROBUSTNESS ACROSS ALTERNATIVE SPECIFICATIONS OF GOVERNMENT FINANCES

Note: Regression results are derived from a regression equation having the variable specification of column 2 of Table 3, supplemented with the respective interaction dummy variables (cf. the text for further details). The estimation procedure is FGLS (weighting on groupwise heteroscedasticity) with robust VCE for heteroscedasticity and cross-sectional correlation. The first column reproduces previous results for comparison's sake (cf. the next to last row of Table 4). "Non-Tax Revenues" are defined as General Revenues minus Total Taxes divided by income. "Welfare" is defined as Direct General Expenditures on Public Welfare divided by income. 
It is interesting to note that the negative tax effects are close in size to the corresponding negative effects associated with Non-Tax Revenues. ${ }^{27}$ This is consistent with an interpretation that both variables are measuring negative effects associated with a larger public sector, and that the added, distortionary effects of taxes are negligible.

On the other hand, the positive and statistically significant coefficients for the welfare variables are puzzling. A possible explanation is that transfer payments are almost exclusively received by state residents, and hence, contribute directly to state income. ${ }^{28}$ In contrast, other government expenditures can be diverted outside the state's economy (e.g., as payments to out-of-state suppliers of government services or supplies), so that the corresponding stimulative spending effects may not contribute to income growth within the state.

\section{WHY HAVE PREVIOUS STUDIES FOUND IT DIFFICULT TO ESTIMATE ROBUST TAX EFFECTS?}

In this section I show that annual data produces substantially different estimates of tax effects compared to five-year interval data. This may provide an explanation for why previous studies have found it difficult to estimate robust tax effects.

Column 1 of Table 9 uses OLS to estimate an annual analogue to the variable specification of column 2 in Table 3 . The data cover 1970-1999 and include the log of capital, employment, and population, along with state and annual time fixed effects and a number of other control variables. The dependent variable is the log of real PCPI. I begin by following the conventional practice of only including contemporaneous values of the explanatory variables.

In contrast to the prior results, I now estimate a positive relationship between tax burden and state incomes. A one-percentage point increase in tax burden is estimated to increase real state PCPI by 0.16 percent. Further, the coefficient is significant well below the five percent level, with a $t$-value of just over three.

To check the sensitivity of this result, I drop various sets of variables from the specification of column 1 . Column 2 drops the capital, employment, population, and lagged income variables. Column 3 drops these, plus the control variables. Column 4 drops these, plus all fixed effects. While the tax coefficient remains positive throughout, its size and statistical significance is unstable across specifications.

A somewhat different picture emerges when the specification is broadened to allow lagged effects. Column 5 reports the results of adding lagged values of the tax burden variable to the specification of column 1. While the contemporaneous relationship between tax burden and income growth remains positive, lagged values of tax burden are estimated to be negatively associated with state income.

This suggests that previous studies may have failed to identify a negative relationship between taxes and income growth because they relied on specifications that used annual data and did not allow for lagged tax effects. My analysis suggests that tax policies take time to work its full effects on the economy. When the specification is sufficiently general to pick up these effects, a negative relationship between taxes and income growth emerges.

The use of annual data may also have contributed to previous findings

\footnotetext{
27 We cannot reject the null hypothesis that the coefficients associated with the difference and level forms of the two kinds of revenues are the same. The associated $p$-values for the specifications of columns 2 and 3 are 0.51 and 0.47 .

28 State Personal Income as measured by the BEA includes transfer payments.
} 
TABLE 9

ESTIMATION OF THE RELATIONSHIP BETWEEN TAX BURDEN AND INCOME GROWTH USING ANNUAL DATA

\begin{tabular}{|c|c|c|c|c|c|}
\hline & $(1)$ & $(2)$ & (3) & $(4)$ & $(5)$ \\
\hline TaxBurden & $\begin{array}{c}0.0016 \\
(3.06)\end{array}$ & $\begin{array}{c}0.0017 \\
(1.11)\end{array}$ & $\begin{array}{c}0.0174 \\
(8.77)\end{array}$ & $\begin{array}{c}0.0040 \\
(1.16)\end{array}$ & $\begin{array}{c}0.0064 \\
(6.27)\end{array}$ \\
\hline TaxBurden(-1) & - & - & - & - & $\begin{array}{c}-0.0025 \\
(-1.96)\end{array}$ \\
\hline TaxBurden(-2) & - & - & - & - & $\begin{array}{c}-0.0020 \\
(-1.62)\end{array}$ \\
\hline TaxBurden(-3) & - & - & - & - & $\begin{array}{c}-0.0001 \\
(-0.11)\end{array}$ \\
\hline TaxBurden $(-4)$ & - & - & - & - & $\begin{array}{c}-0.0025 \\
(-2.63)\end{array}$ \\
\hline LNK & $\begin{array}{c}0.0754 \\
(8.84)\end{array}$ & - & - & - & $\begin{array}{c}0.0936 \\
(9.97)\end{array}$ \\
\hline$L N L$ & $\begin{array}{c}0.1073 \\
(8.19)\end{array}$ & - & - & - & $\begin{array}{c}0.1330 \\
(9.79)\end{array}$ \\
\hline$L N N$ & $\begin{array}{c}0.0064 \\
(5.91)\end{array}$ & - & - & - & $\begin{array}{c}0.0034 \\
(3.29)\end{array}$ \\
\hline$L N Y_{-} 1$ & $\begin{array}{l}0.7466 \\
(65.25)\end{array}$ & - & - & - & $\begin{array}{l}0.7180 \\
(55.54)\end{array}$ \\
\hline Education & $\begin{array}{l}0.0034 \\
(10.38)\end{array}$ & $\begin{array}{l}0.0174 \\
(20.17)\end{array}$ & - & - & $\begin{array}{l}0.0038 \\
(10.62)\end{array}$ \\
\hline Working population & $\begin{array}{l}0.0056 \\
(11.85)\end{array}$ & $\begin{array}{l}0.0288 \\
(25.28)\end{array}$ & - & - & $\begin{array}{l}0.0055 \\
(11.19)\end{array}$ \\
\hline Nonwhite & $\begin{array}{c}-0.0004 \\
(-2.84)\end{array}$ & $\begin{array}{c}-0.0008 \\
(-2.38)\end{array}$ & - & - & $\begin{array}{c}-0.0001 \\
(-1.09)\end{array}$ \\
\hline Female & $\begin{array}{l}0.0112 \\
(8.33)\end{array}$ & $\begin{array}{c}-0.0014 \\
(-0.37)\end{array}$ & - & - & $\begin{array}{c}0.0127 \\
(8.95)\end{array}$ \\
\hline Agriculture & $\begin{array}{l}0.0028 \\
(12.11)\end{array}$ & $\begin{array}{l}0.0057 \\
(11.53)\end{array}$ & - & - & $\begin{array}{c}0.0015 \\
(5.11)\end{array}$ \\
\hline Mining & $\begin{array}{c}-0.0005 \\
(-1.16)\end{array}$ & $\begin{array}{c}0.0029 \\
(4.80)\end{array}$ & - & - & $\begin{array}{c}-0.0011 \\
(-2.74)\end{array}$ \\
\hline Union & $\begin{array}{c}0.0008 \\
(5.31)\end{array}$ & $\begin{array}{l}0.0049 \\
(15.24)\end{array}$ & - & - & $\begin{array}{l}0.0013 \\
(8.45)\end{array}$ \\
\hline Diversity & $\begin{array}{c}0.0032 \\
(7.06)\end{array}$ & $\begin{array}{c}0.0039 \\
(3.17)\end{array}$ & - & - & $\begin{array}{c}0.0017 \\
(3.10)\end{array}$ \\
\hline Other variables & $\begin{array}{l}\text { state fixed } \\
\text { effects, year } \\
\text { fixed effects }\end{array}$ & $\begin{array}{l}\text { state fixed } \\
\text { effects, year } \\
\text { fixed effects }\end{array}$ & $\begin{array}{l}\text { state fixed } \\
\text { effects, year } \\
\text { fixed effects }\end{array}$ & - & $\begin{array}{l}\text { state fixed } \\
\text { effects, year } \\
\text { fixed effects }\end{array}$ \\
\hline Number of observations & 1440 & 1440 & 1440 & 1440 & 1248 \\
\hline$R^{2}$ & 0.994 & 0.944 & 0.843 & 0.448 & 0.993 \\
\hline
\end{tabular}

Note: The dependent variable is the log of real Per Capita Personal Income (1984 dollars). All equations are estimated using OLS. $t$-statistics are reported in parenthesis. 
of coefficient instability. Though they are positively correlated, tax burden has been demonstrated to substantially mismeasure state tax policy (Reed and Rogers, 2006, 2007). Annual data are more vulnerable to measurement error bias than five-year interval data. Consequently, it would not be surprising if estimates of tax effects based on annual data were prone to instability depending on the particular distribution of measurement errors in the sample. This may be an additional reason why previous studies have had difficulty identifying robust tax effects.

\section{CONCLUSION}

Using five-year data from 1970-1999 and the 48 continental states, I find that both (1) contemporaneous changes and (2) lagged levels of taxes are negatively and significantly related to income growth. The estimated effects vary depending on variable specification; estimation procedure; time period, region, and state; and the manner in which the data are organized into five-year intervals. Nevertheless, the finding of negative and statistically significant tax effects is generally robust across all of these dimensions, with one exception: State-specific estimates of tax effects widely vary. This latter result may be explained by the narrow parsing of the data. At this level of analysis there are only six observations per state-specific tax coefficient.

These results are surprising given that previous studies have had difficulty identifying a robust relationship between state taxes and incomes. My analysis suggests that this may be because previous studies of state income growth have tended to use annual data, have differed in their vari- able specifications, and have not allowed for lagged tax effects. When I use annual data and restrict the analysis to contemporaneous tax effects, I estimate positive tax effects, but the sizes and significances of the tax coefficient greatly vary depending on variable specification. When I include lagged values of the tax variable, a negative relationship between taxes and growth emerges. This lack of robustness is not apparent in the five-year interval data. This may be because the variables interact over time in complex ways that are difficult to model. It may also be that the data-for definitional and measurement reasons-are not well-suited to relating to each other at the annual level.

It needs to be emphasized that my claim for robustness should be understood as applying only within the context of U.S. state income growth. It should not be interpreted as being more widely applicable to other contexts, such as employment growth, manufacturing activity, plant locations, etc., or to the relationship between taxes and income growth outside the U.S.

Much work remains to be done before reliable estimates of tax effects can be obtained.$^{29}$ However, this study establishes that there is a durable empirical relationship between taxes and U.S. state income growth that warrants further investigation. Obtaining a better understanding of the nature and cause of that relationship is a potentially fruitful avenue for future research. It is hoped that this study will stimulate efforts towards that end.

\section{Acknowledgments}

I am very appreciative to Steve Yamarik for providing data on state capital stocks

29 A key remaining issue is the problem of endogeneity between tax policy and economic conditions. Policymakers frequently raise taxes during economic downturns, and lower taxes during times of economic prosperity (Poterba, 1994). This generates a negative bias to estimates of contemporaneous tax effects. While this cannot explain why I find a negative, lagged effect for tax burden (cf. the coefficient for TaxBurden[L]), it may contribute to the estimated, negative effect for contemporaneous changes in the tax burden variable (cf. the coefficient for TaxBurden[D]). 
(cf. Garofalo and Yamarik, 2002). I acknowledge helpful comments from Steve Yamarik, Bob Tannenwald, seminar participants at the Motu Economic and Public Policy Research Institute, the National Tax Association meetings, two anonymous referees, and the editor. Culpability for remaining errors is mine alone.

\section{REFERENCES}

Alm, James, and Janet Rogers.

"Do State Fiscal Policies Affect Economic Growth?" Department of Economics, Andrew Young School of Policy Studies, Georgia State University. Mimeo, 2005.

Aschauer, David Alan.

"Do States Optimize? Public Capital and Economic Growth." The Annals of Regional Science 34 No. 3 (September, 2000): 343-63.

Bania, Neil, Jo Anna Gray, and Joe A. Stone. "Growth, Taxes, and Government Expenditures: Growth Hills for U.S. States." National Tax Journal 60 No. 3 (June, 2007): 193-204.

Bartik, Timothy J.

Who Benefits from State and Local Economic Development Policies? Kalamazoo, MI: W.E. Upjohn Institute for Employment Research, 1991.

Bassanini, Andrea, Scarpetta, Stefano, and Philip Hemmings.

"Economic Growth: The Role of Policies and Institutions. Panel Data Evidence from OECD Countries." Economics Department, Organization for Economic Co-operation and Development (OECD). OECD Working Paper No. 283. OECD Economics Department, 2001.

Beck, Nathaniel, and Jonathan N. Katz.

"What to Do (and Not to Do) with Time-Series Cross-Section Data." American Political Science Review 89 No. 3 (September, 1995): 634-47.

Becsi, Zsolt.

"Do State and Local Taxes Affect Relative State Growth?" Economic Review 81 No. 2 (March/April, 1996): 18-36.

Bureau of Economic Analysis (BEA). http://www.bea.gov/regional/index.htm.
Caplan, Bryan.

"Has Leviathan Been Bound? A Theory of Imperfectly Constrained Government with Evidence from the States." Southern Economic Journal 67 No. 4 (April, 2001): 825-47.

Carroll, Robert, and Wasylenko, Michael.

"Do State Business Climates Still Matter? Evidence of a Structural Change." $\mathrm{Na}$ tional Tax Journal 47 No. 1 (March, 1994): 19 37.

Caselli, Francesco, and Wilbur John

Coleman II.

"Cross-Country Technology Diffusion: The Case of Computers." American Economic Review 91 No. 2 (May, 2001): 328-35.

Chernick, Howard.

"Tax Progressivity and State Economic Performance." Economic Development Quarterly 11 No. 3 (August, 1997): 249-67.

Ciccone, Antonio, and Robert E. Hall.

"Productivity and the Density of Economic Activity." American Economic Review 86 No. 1 (March, 1996): 54-70.

Clark, David E., and Christopher A. Murphy. "Countywide Employment and Population Growth: An Analysis of the 1980s." Journal of Regional Science 36 No. 2 (May, 1996): 235-56.

Crain, W. Mark, and Katherine J. Lee.

"Economic Growth Regressions for the American States: A Sensitivity Analysis." Economic Inquiry 37 No. 2 (April, 1999): 242-57.

Crown, William H., and Leonard F. Wheat. "State Per Capita Income Convergence Since 1950: Sharecropping's Demise and Other Influences." Journal of Regional Science 35 No. 4 (November, 1995): 527-52.

Dalenberg, Douglas R., and Mark D. Partridge. "The Effects of Taxes, Expenditures, and Public Infrastructure on Metropolitan Area Employment." Journal of Regional Science 35 No. 4 (November, 1995): 617-40.

Evans, Paul, and George Karras.

"Are Government Activities Productive? Evidence from a Panel of U.S. States." The Review of Economics and Statistics 76 No. 1 (February, 1994): 1-11. 
Garofalo, Gasper A., and Steven Yamarik. "Regional Convergence: Evidence from a New State-by-State Capital Stock Series." The Review of Economics and Statistics 84 No. 2 (May, 2002): 316-23.

Garcia-Milà, Teresa, and Therese J. McGuire. "The Contribution of Publicly Provided Inputs to States' Economies." Regional Science and Urban Economics 22 No. 2 (July, 1992): 229-41.

Garcia-Milà, Teresa, and Therese J. McGuire. "Industrial Mix as a Factor in the Growth and Variability of States' Economies." Regional Science and Urban Economics 23 No. 6 (December, 1993): 731-48.

Garcia-Milà, Teresa, Therese J. McGuire, and

Robert H. Porter.

"The Effect of Public Capital in State-Level Production Functions Reconsidered." The Review of Economics and Statistics 78 No. 1 (February, 1996): 177-80.

Greene, William H.

Econometric Analysis, 333f, fifth edition. Upper Saddle River, NJ: Prentice Hall, 2003.

Helms, Jay.

"The Effect of State and Local Taxes on Economic Growth: A Time Series-Cross Section Approach." Review of Economics and Statistics 67 No. 4 (November, 1985): 574-82.

Hirsch, Barry T., David A. MacPherson, and Wayne G. Vroman.

"Estimates of Union Density by State." Monthly Labor Review 124 No. 7 (July, 2001): 51-5.

Holtz-Eakin, Douglas.

"Solow and the States: Capital Accumulation, Productivity, and Economic Growth." National Tax Journal 46 No. 4 (December, 1993): 425-40.

Holtz-Eakin, Douglas.

"Public Sector Capital and the Productivity Puzzle." The Review of Economics and Statistics 76 No. 1 (February, 1994): 12-21.

Knight, Brian G.

"Supermajority Voting Requirements for Tax Increases: Evidence from the States." Journal of Public Economics 76 No. 1 (April, 2000): 41-67.
Leamer, Edward E.

"Sensitivity Analyses Would Help." American Economic Review 75 No. 3 (June, 1985): 308-13.

Levine, Ross, and David Renelt.

"A Sensitivity Analysis of Cross-Country Growth Regressions." American Economic Review 82 No. 4 (September, 1992): 942-63.

Mankiw, N. Gregory, David Romer, and David N. Weil.

"A Contribution to the Empirics of Economic Growth." The Quarterly Journal of Economics 107 No. 2 (May, 1992): 407-37.

McGuire, Therese.

"Review of 'Who Benefits from State and Local Economic Development Policies'." National Tax Journal 45 No. 4 (December, 1992): 457-9.

Merriman, David.

"Public Capital and Regional Output: Another Look at Some Japanese and American Data." Regional Science and Urban Economics 20 No. 4 (February, 1990): 437-58.

Mitchener, Kris James, and Ian W. McLean. "The Productivity of U.S. States Since 1880." Journal of Economic Growth 8 No. 1 (March, 2003): 73-114.

Mofidi, Alaeddin, and Joe Stone.

"Do State and Local Taxes Affect Economic Growth?" Review of Economics and Statistics 72 No. 4 (November, 1990): 686-91.

Mullen, John, and Williams, Martin.

"Marginal Tax Rates and State Economic Growth." Regional Science and Urban Economics 24 No. 6 (December, 1994): 687-705.

Nickell, Stephen.

"Biases in Dynamic Models with Fixed Effects." Econometrica 49 No. 6 (November, 1981): 1417-27.

Partridge, Mark D., and Dan S. Rickman. "The Role of Industry Structure, Costs, and Economic Spillovers in Determining State Employment Growth Rates." Review of Regional Studies 26 No. 3 (Winter, 1996): 235-64.

Phillips, Joseph, and Ernest Goss.

"The Effect of State and Local Taxes on Economic Development: A Meta-Analysis." Southern Economic Journal 62 No. 2 (October, 1995): 320-33. 
Plaut, Thomas R., and Joseph E. Pluta.

"Business Climate, Taxes and Expenditures, and State Industrial Growth in the United States." Southern Economic Journal 50 No. 1 (July, 1983): 99-109.

Poterba, James M.

"State Responses to Fiscal Crises: The Effects of Budgetary Institutions and Politics." Journal of Political Economy 102 No. 4 (August, 1994): 799-821.

Reed, W. Robert.

"Democrats, Republicans, and Taxes: Evidence that Political Parties Matter." Journal of Public Economics 90 No. 4-5 (May, 2006): 725-50.

Reed, W. Robert.

"The Determinants of U.S. State Economic Growth: A Less Extreme Bounds Analysis." Economic Inquiry (forthcoming).

Reed, W. Robert, and Cynthia Rogers.

"Tax Burden and the Mismeasurement of State Tax Policy." Public Finance Review 34 No. 4 (July, 2006): 404-26.

Reed, W. Robert, and Cynthia Rogers.

"A Method for Identifying the Effects of Income and Tax Policy on State Tax Revenues." Department of Economics, University of Canterbury. Mimeo, 2007.

Romans, Thomas, and Ganti Subrahmanyam. "State and Local Taxes, Transfers, and Regional Economic Growth." Southern Economic Journal 46 No. 2 (October, 1979): 435-44.

Roodman, David.

"How to Do xtabond2: An Introduction to 'Difference' and 'System' GMM in Stata." Working Paper No. 103. Washington, D.C.: Center for Global Development, December, 2006.
Sala-i-Martin, Xavier, Gernot Doppelhofer, and Ronald I. Miller.

"Determinants of Long-Term Growth: A Bayesian Averaging of Classical Estimates (BACE) Approach." American Economic Review 94 No. 4 (September, 2004): 813-35. Shioji, Etsuro.

"Public Capital and Economic Growth: A Convergence Approach." Journal of Economic Growth 6 No. 3 (September, 2001): 205-27.

Stansel, Dean.

"Local Decentralization and Local Economic Growth: A Cross-sectional Examination of U.S. Metropolitan Areas." Journal of Urban Economics 57 No. 1 (January, 2005): 55-72.

Tomljanovich, Marc.

"The Role of State Fiscal Policy in State Economic Growth." Contemporary Economic Policy 22 No. 3 (July, 2004): 318-30.

U.S. Census Bureau (Census). http://www.census.org.

Wasylenko, Michael.

"Taxation and Economic Development: The State of the Economic Literature." New England Economic Review (March/April 1997): 37-52.

Wasylenko, Michael, and Therese McGuire. "Jobs and Taxes: The Effect of Business Climate on State Employment Growth Rates." National Tax Journal 38 No. 4 (December, 1985): 497-511.

Yamarik, Steven.

"Can Tax Policy Help Explain State-Level Macroeconomic Growth?" Economics Letters 68 (2000): 211-5.

Yamarik, Steven.

"Tax Policy and State Economic Development." California State University. Mimeo, 2004. 


\section{APPENDIX}

\section{STATISTICAL SUMMARY OF DATA}

\begin{tabular}{|c|c|c|c|c|c|}
\hline \multicolumn{2}{|l|}{ Variable } & Mean & Std. Deviation & Minimum & Maximum \\
\hline \multicolumn{2}{|l|}{$D L N Y^{1}$} & 8.23 & 5.20 & -9.38 & 40.45 \\
\hline \multicolumn{2}{|l|}{$D L N K^{2}$} & 7.42 & 7.81 & -26.92 & 55.43 \\
\hline \multicolumn{2}{|l|}{$D L N L^{3}$} & 4.66 & 3.99 & -7.22 & 14.97 \\
\hline \multicolumn{2}{|l|}{$D L N N^{4}$} & 4.63 & 4.48 & -8.63 & 21.45 \\
\hline \multirow[t]{2}{*}{ Tax burden ${ }^{5}$} & D & 0.13 & 0.88 & -5.52 & 5.91 \\
\hline & $\mathrm{L}$ & 10.87 & 1.37 & 7.92 & 19.27 \\
\hline \multirow[t]{2}{*}{ Education $^{6}$} & $\mathrm{D}$ & 1.77 & 0.55 & 0.34 & 3.21 \\
\hline & $\mathrm{L}$ & 16.41 & 4.92 & 6.66 & 30.21 \\
\hline \multirow[t]{2}{*}{ Working population 6} & $\mathrm{D}$ & 0.97 & 0.93 & -1.22 & 2.93 \\
\hline & $\mathrm{L}$ & 55.84 & 3.18 & 47.54 & 62.26 \\
\hline \multirow[t]{2}{*}{ Nonwhite $^{6}$} & $\mathrm{D}$ & 0.56 & 0.51 & -0.98 & 2.42 \\
\hline & $\mathrm{L}$ & 11.75 & 8.76 & 0.36 & 37.35 \\
\hline \multirow[t]{2}{*}{ Female $^{6}$} & D & -0.02 & 0.15 & -0.57 & 0.75 \\
\hline & $\mathrm{L}$ & 51.23 & 0.77 & 48.77 & 52.76 \\
\hline Population $^{6}$ & $\mathrm{~L}$ & 14.93 & 1.00 & 12.72 & 17.27 \\
\hline \multirow{2}{*}{ Population density ${ }^{6}$} & $\mathrm{D}$ & 4.93 & 6.68 & -8.44 & 37.26 \\
\hline & $\mathrm{L}$ & 162.25 & 230.78 & 3.44 & 1089.83 \\
\hline \multirow[t]{2}{*}{$U_{r b a n^{6}}$} & $\mathrm{D}$ & 0.75 & 1.13 & -1.97 & 3.96 \\
\hline & $\mathrm{L}$ & 67.18 & 14.43 & 32.16 & 93.54 \\
\hline \multirow[t]{2}{*}{ Agriculture $^{6}$} & D & -0.06 & 2.46 & -16.72 & 18.85 \\
\hline & $\mathrm{L}$ & 3.28 & 3.98 & -8.92 & 29.06 \\
\hline \multirow[t]{2}{*}{ Manufacturing ${ }^{6}$} & D & -0.81 & 1.68 & -6.09 & 3.37 \\
\hline & $\mathrm{L}$ & 20.93 & 8.42 & 3.73 & 40.49 \\
\hline \multirow[t]{2}{*}{ Service $^{6}$} & D & 1.47 & 1.25 & -3.22 & 6.40 \\
\hline & $\mathrm{L}$ & 19.51 & 5.65 & 10.93 & 41.55 \\
\hline \multirow[t]{2}{*}{ Mining 6} & $\mathrm{D}$ & -0.19 & 0.76 & -3.29 & 4.27 \\
\hline & $\mathrm{L}$ & 2.15 & 3.53 & 0.02 & 24.98 \\
\hline \multirow[t]{2}{*}{ Union $^{6}$} & $\mathrm{D}$ & -1.47 & 2.36 & -10.6 & 5.0 \\
\hline & $\mathrm{L}$ & 18.48 & 8.12 & 3.3 & 41.7 \\
\hline \multirow[t]{2}{*}{ Diversity $^{6}$} & $\mathrm{D}$ & -0.06 & 0.77 & -5.42 & 4.66 \\
\hline & $\mathrm{L}$ & 17.36 & 2.05 & 13.84 & 23.56 \\
\hline \multicolumn{2}{|l|}{$L N Y \_1^{7}$} & 2.53 & 0.20 & 1.96 & 3.06 \\
\hline \multirow[t]{2}{*}{ NonTaxRevenues $^{8}$} & $\mathrm{D}$ & 0.33 & 0.93 & -2.13 & 6.26 \\
\hline & $\mathrm{L}$ & 8.16 & 2.29 & 3.44 & 20.13 \\
\hline \multirow[t]{2}{*}{ Welfare $^{9}$} & $\mathrm{D}$ & 0.19 & 0.52 & -1.70 & 2.88 \\
\hline & $\mathrm{L}$ & 2.15 & 0.83 & 0.75 & 5.30 \\
\hline
\end{tabular}

Variable Descriptions:

${ }^{1} D L N Y$ is the percent change in real Per Capita Personal Income (1984 dollars).

${ }^{2} D L N K$ is the percent change in net private Capital Stock created through 1-digit SIC industries (measured in millions of chained 1996 dollars). These data were provided by Steve Yamarik (cf. Garofalo and Yamarik, 2002).

${ }^{3} D L N L$ is the percent change in total employment (source: BEA).

${ }^{4} D L N N$ is the percent change in total population (source: Census).

${ }^{5}$ Tax burden is the ratio of total state and local tax revenues over total state personal income.

${ }^{6}$ These variables are described in Table 2. " $\mathrm{D}$ " denotes the five-year difference in the variable over the period $(t$ $-4, t)$. " $L$ " denotes the value of the variable at the beginning of the five-year period.

${ }^{7} L N Y \_1$ is the value of the log of real Per Capita Personal Income (1984 dollars) at the beginning of the five-year period.

${ }^{8 " N o n T a x R e v e n u e s " ~ i s ~ d e f i n e d ~ a s ~ G e n e r a l ~ R e v e n u e s ~(s t a t e ~+~ l o c a l) ~ m i n u s ~ T o t a l ~ T a x e s ~(s t a t e ~+~ l o c a l) ~ d i v i d e d ~ b y ~}$ Personal Income at the start of the fiscal year (source: Census).

"Welfare" is defined as Direct General Expenditure of State and Local Governments on Public Welfare divided by Personal Income at the start of the fiscal year (source: Census). 